\title{
Abbreviations and Symbols
}

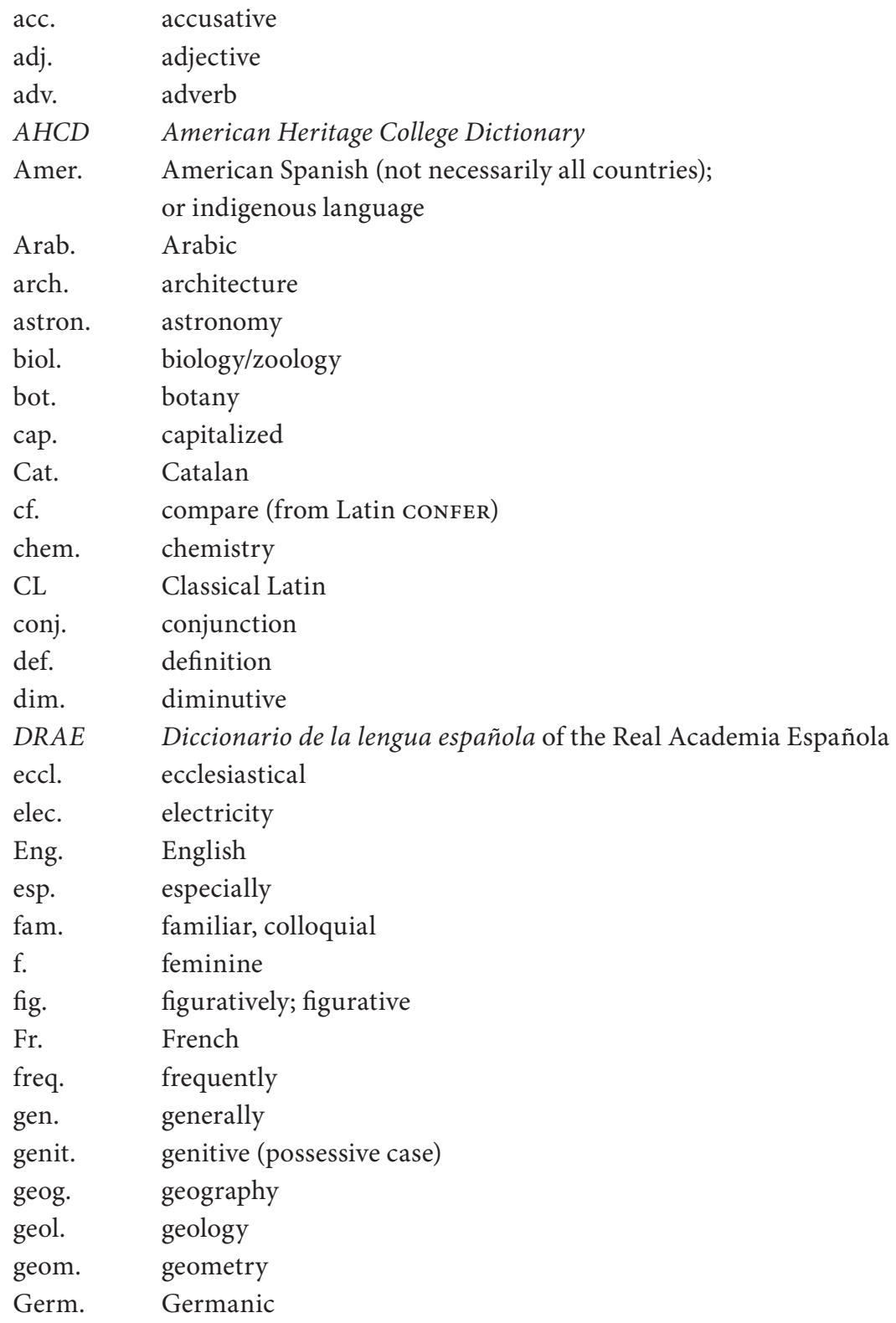




\begin{tabular}{|c|c|}
\hline gram. & grammar \\
\hline Gk. & Greek \\
\hline incl. & including \\
\hline inf. & infinitive \\
\hline It. & Italian \\
\hline Lat. & Latin \\
\hline lit. & literally \\
\hline m. & masculine \\
\hline m./f. & masculine/feminine \\
\hline math. & mathematics \\
\hline med. & medicine \\
\hline mil. & military \\
\hline Mod.Fr. & Modern French \\
\hline Mod.Sp. & Modern Spanish \\
\hline n. & noun \\
\hline neg. & negative \\
\hline n.f. & feminine noun \\
\hline n.m. & masculine noun \\
\hline n.m./f. & noun both masculine and feminine \\
\hline nom. & nominative \\
\hline obs. & obsolete or archaic \\
\hline OED & Oxford English Dictionary \\
\hline OldEng. & Old English \\
\hline OldFr. & Old French \\
\hline OldSp. & Old Spanish \\
\hline onom. & onomatopoeia \\
\hline orig. & originally \\
\hline part. & participle \\
\hline pert. & pertaining \\
\hline pl. & plural \\
\hline Port. & Portuguese \\
\hline p.p. & past participle $^{1}$ \\
\hline prep. & preposition \\
\hline pres. & present \\
\hline RAE & Real Academia Española (see also DRAE) \\
\hline sing. & singular \\
\hline s.o. & someone \\
\hline Sp. & Spanish \\
\hline
\end{tabular}

${ }^{1}$ Used generally in cases where the definition corresponding to the past participle is not presented among the accompanying list of definitions. 


$\begin{array}{ll}\text { UK } & \text { United Kingdom } \\ \text { vb. } & \text { verb } \\ \text { VL } & \text { Vulgar Latin } \\ \text { w/out } & \text { without } \\ & \\ \sim & \text { is similar in meaning to (always refers to two Spanish words) } \\ < & \text { is derived from (e.g., soprano }<\text { It., sport }<\text { disport) } \\ = & \text { is equal to } \\ \neq & \text { is not equal to } \\ \dagger & \text { indicates that an English word used as a cognate is "obsolete" or } \\ & \text { "archaic" } 2\end{array}$

${ }^{2}$ In general, this applies to words that either: (a) are listed as "obsolete" or "archaic" in Webster's Third New International Dictionary, Unabridged or (b) are not found there but appear in the Oxford English Dictionary. The term rare is used to mark other cognates that, while perhaps not technically obsolete or archaic, are not normally found in "smaller" dictionaries (e.g., American Heritage College Dictionary). 